\title{
THE COMPARISON BETWEEN RIGHT HEMISPHERE DOMINANCE STUDENTS AND LEFT ONE IN MULTIPLE CHOICE OF ENGLISH TEST AT THE FIRST GRADE MAN 2 OF PAMEKASAN
}

\author{
Laily Komaril Syafrilia \\ English Teaching and Learning Program, Tarbiyah Faculty, IAIN Madura \\ Mosleh Habibullah \\ English Teaching and Learning Program, Tarbiyah Faculty, IAIN Madura \\ moslehhabibullah@gmail.com
}

\begin{abstract}
The brain is divided into two nearly symmetrical halves, the right, and the left hemisphere. Left hemisphere handles all of analytical, logical matters, and language skill. On the contrary, art objects such as music, imagination, and colors handled by the right one. This research investigated whether there is a significant difference between right hemisphere dominance students and left one in multiple choice of English test. The researcher used ex-post facto research. The population is 294 of first-grade students. The simple random sampling technique used to select 40 students 20 right hemisphere dominance students and 20 left one). In gaining the data, three instruments have been used namely questionnaire, test, and documentation. The data were analyzed using independent t-test. The result revealed that there is a significant difference between right hemisphere dominance students and left one at the first grade MAN 2 of Pamekasan in multiple choice of English test (2.16 > 2.03; Significance level 5\%, $d f=35$ ). Left brain dominance students are better in multiple choice of English test because language skill is placed on the left hemisphere. It also notified that differ hemisphere dominance students give different effect to the students' achievement in English testing, especially multiple-choice test.
\end{abstract}

Keywords: Right Hemisphere Dominance Students; Left Hemisphere Dominance Students; Multiple Choice Test

First Received:

September 3rd, 2019
Final Proof Received: September 9th, 2019

\section{INTRODUCTION}

Human is the best creatures. He can do everything to manage this world because he has complete "tools". It is stated in Al-Quran Surah At-Tiin fourth verse (The Qur'an Arabic Text with Corresponding Meanings, 1997: 894):

$$
\text { " "We have certainly created man in the best of stature;" }
$$

Ibnu Katsir explicates that verse by deep explanation. He explains that fourth verse becomes the oath subject of three previous verses. The fourth verse is the reason why the oath was made (Muhammad, 2008: 382). It might be expected that the fourth verse is urgent by three previous verses which must be placed in before the fourth one. 
Laily Komaril Syafrilia, and Mosleh Habibullah, The Comparison Between Right Hemisphere...

"By the fig and the olive, And [by] Mount Sinai, And [by] this secure city"(At-Tiin: 1-3)

The phrase "The best of stature" means that human has the best condition and normal body. It is because he has three aspects of human normality namely good performance (i.e., upright, symmetrical, and balanced in form and nature), feeling (physical sense), and mind. The last aspect is the distinction between human and animal. Furthermore, mind and brain can't be separated because mind is the content and brain is the container. In other words, thought is brain's activity (Kalat, 2011: 7). Thus, brain is crucial thing for human being.

The brain is divided into two nearly symmetrical halves, the right and the left hemisphere, each of which is responsible for processing certain kinds of information concerning the world around us (Chomsky, 1994: 252). It could be seen from its structure. Furthermore, to specify the brain's work system, in 1960s (Tea, 2009: 97), a great prominent scientist Roger Sperry from Chicago University (Tea, 2009) got Nobel Prize because of his invention in physiology field (Busan, 2005: 15) (physiology is branch of science which explains the function of every organ based on its structure and its form). Sperry claimed that brain tends to divide the activities into two different categories. The first category is including to the left hemisphere which is handled all of analytical and logical matters. On the contrary, the art objects such as music, imagination, and colors are including to the right hemisphere. In similar corridor, Alan Pritchard stated in his book by quoting Rose and Nicholl's statement "Some brain research has pointed to the notion that the two hemispheres of the brain having different functions: "The left hemisphere specializes in academic aspects of learning - language and mathematical processes, logical thoughts, sequences and analysis. The right hemisphere is principally concerned with creative activities utilizing rhyme, rhythm, music, visual impressions, color and pictures" (Pritchard, 2009: 87). In simpler words, one hemisphere is predominantly concerned with the logical and the other with the more creative.

Before Sperry achievement, in 1861 Paul Broca, a French brain surgeon/neurologist implicitly had proven Sperry's theory by his observation (Capacchione, 2001: 34). He observed his patients whose left hemisphere was damaged by lesion. Because of that, his patient had lost his speech ability. This small region in the third convolution of the left frontal lobe of the cerebral cortex became known as Broca's area (Capacchione, 2001). Moreover, in 1875 Carl Wernicke in another clinical case study found an injury which damaged left frontal lobe near of cerebral cortex in which influence language processing then it is known as Wernicke's area. The difference from Broca's area is placed on the matter. A lesion (severe damage) in the Broca's area is the disability to speak (involves with language production) (Siahaan, 2008: 87). However, language comprehension is Wernicke's (Solso, 2007: 328). It is also stated in Sanggam's book. He remarked (Siahaan, 2008: 85): “Damage to Broca's area is usually associated with non-fluent-speech. Damage to Wernicke's area is usually associated with comprehension disturbances". 
Testing language is another essential ingredient of language comprehension. It is a complex social phenomenon because it has evolved to fulfill a number of functions in the classroom (Fulcher, 2010: 1). It is used as tools to measure the students' achievements namely achievement of second language acquisition using score or numerical data, likewise Haladyna's statement (Haladyna, 2004: 4): "A test is a measuring device intended to describe numerically the degree or amount of learning under uniform, standardized conditions." David P. Harris mentions in his book there are six techniques of language testing namely translation, dictation, composition, scored interview, multiple choice items, and short-answer items (Harris, 1969: 4). Subsequently, after reading that book, it may be inferred that multiple choice items have more benefit than another language testing technique which will describe in next chapter in detail.

MAN 2 of Pamekasan is one of Islamic Senior High School in Pamekasan whose good standard in measuring its disciples' achievements by using multiple choices in certain chance such as daily examination and middle test. Multiple choice or selection item type is kind of language testing which is developed to overcome a number of the weaknesses of the composition test that others language testing have (Harris, 1969: 7). The weaknesses of another language testing have such as extremely difficult to evaluate (translation test), uneconomical, and imprecise (dictation test) (Harris, 1969). Multiple choices generally can be answered fairly rapidly, the test maker can include a large number of different tasks, and scoring can be done quickly (Harris, 1969). However, Ms. Khorijah Widi Astutik, S.Pd (2014) as MAN's English teacher for first grade science program confessed that not all of students are getting standard score to pass certain test. Even she said only two or three students who are successful in passing those kinds test though she gives permission for students to open dictionary.

Another MAN's English Teacher, Mr. Mohammad Zainollah (2014) as third grade teacher social program, admitted same thing. He explained that most of students in third class got low score in multiple choice test. Thus, it is often for him to not only "scoring" but also "giving score" for students.

Consequently, for the sake of getting standard score to pass the test, the students will do anything to pass the test, for instance they make a deal to cheat each other.

In accordance to explanations above, the researcher expects that it is an interesting study to be conducted of The Comparison between Right Hemisphere Dominance Students and Left One in Multiple Choice of English Test at the First Grade MAN 2 of Pamekasan to make all of the first grade students at MAN 2 of Pamekasan better in managing themselves in facing multiple choice test to measure their achievement in language skill namely English subject based on their hemisphere dominances. 


\section{LITERATURE REVIEW}

\section{Split Brain; the History}

In second half the $20^{\text {th }}$ century, Roger Sperry as great scientist who has big anxiety in brain world measured the function of two brain hemispheres. He set a hat look-like on his disciples which was connected with electrical cables to measure the waves which spouted by brain while his disciples were doing certain and particular activities such as reading poem, staring picture, thinking logically, imagining, etc. The result is somewhat surprising (Busan, 2005: 15).

Professor Sperry found that brain tends to separate those activities into two categories. The first category of activity is handled by left hemisphere whereas another category of activity is handled by right one. The left hemisphere is dominant over analytical and verbal tasks while the right one deals with spatial, visual, and emotional tasks (Busan, 2005: 15). Because of that, Nobel Prize committee gave him one of reward in physiology field.

\section{The Role of Right and Left Hemisphere}

It has been explained that both hemisphere have different role because there is evidence in neurological research that as the human brain matures, certain function are assigned, or "lateralized" to the left hemisphere of the brain, and certain other functions to the right one (Brown, 2000: 54). Intellectual, logical, and analytic functions appear to be largely located in the left hemisphere, while the right one controls functions related to emotional and social needs (Brown, 2000). Furthermore, it controls the left side of body (Brown, 2000). Language functions appear to be controlled mainly in the left hemisphere. It also controls the right side of body (Siahaan, 2008: 86). It could be seen from Roger Sperry's observations which are provided both from internet and books which are used by researcher.

Language skill is placed on the left hemisphere. However, right hemisphere is important for emotion and gesture. Left hemisphere is truly for language skill, but without right one's role, the utterances will be monotonous, no prosody, no emotion, and flat. Thus, the roles of both hemispheres are needed. President Obama as an example who prospers in maximizing both hemispheres. Mary Lou Décosterd's has formulated some beautiful words in elaborating President Obama's achievement in leading USA because he can maximize well of using his both hemispheres. She declares in her book:

"The brain is divided into two hemispheres: the left and the right. Each brain hemisphere controls specialized preferences in thinking and behaving. A network of fibers connects one hemisphere to the other, allowing for interplay between both sides of the brain. While certain preferences are rooted in one hemisphere or the other, full brain engagement comes through a cross-pollination of right- and left-brain perspectives rather than through the cultivation of polarized camps. Obama's is a perspective of unity and commonality. He is open to disparate viewpoints and seeks ultimately to leverage diversity by bringing camps together to fully integrate thoughts. 
The left hemisphere or left brain is our grounded tactician, able to plan, reason, and execute in the moment. The left brain controls sequential and linear thought. It is where our verbal and analytical abilities come from. It helps us see things as they are. It is ordered, quantitative, logical, realistic, and practical. The left brain reasons from part to whole and communicates in names and labels. It is concerned with facts, discrete parts, verbal expression, careful scrutiny, and closure. Obama is adept at leftbrain logic, expression, order, and analysis. He is very much attuned to the realities of the present. The right hemisphere or right brain is our strategist, innovator, and visionary. It controls intuitive and emotional thought. The right hemisphere is imaginative, nonverbal, and holistic. It reasons from whole to parts, is reflective, and thinks of the world as it could be. The right brain is concerned with future possibilities, with creativity, with change, and with our interpersonal connections. Obama leads from right-brain vision, from a transformational perspective and from interpersonal connections (Décosterd, 2010: 34)."

There is corpus callosum (the structure that connects the left and right hemispheres) which makes them "communicate" each other so that they are able to "work" in controlling human personality (Emmorey, 2002: 293). It answers Obama secret why he is able to maximize both hemispheres. He can stimulate and practice them well.

Abdul Chaer (2009: 120) concludes that there are six points which is usually centralized in left hemisphere, they are reading, writing, guessing, scientific, technology, and thinking rationally. On the other hand, there are three points which are mastered by right hemisphere dominant peoples, those are music and song, idiom language, and complicated gesture and picture comprehending process.

It could be explain that the right hemisphere is best at expressive and creative tasks. In different side, the left hemisphere is considered to be adept at tasks that involve logic, language and analytical thinking. Because of that, to be sure it influences each characteristic. Some of characteristics that are popularly associated with the right hemisphere are include color, images, intuition, creativity, recognizing faces, expressing emotions, and music. The left hemisphere is often described as being better at language, logic, critical thinking, numbers, and reasoning. Those points are similar with other experts' statement such as Prof. Dr. Conny R. Semiawan, Alan Pritchard, Tony Buzan, and Taufik Tea in different diction.

\section{Right Hemisphere Dominance Students and Left One}

Rod Ellis stated that one of factor which is influencing individual learner differences in language learning is hemisphere specialization (Ellis, 1994: 472). It might be said that certain hemisphere dominance students will influence their learning style. It means those of us who are 'left-brained' tend to favor a slow, step-by-step build-up of information; learning proceeds in a linear fashion (Pritchard, 2009: 87). In other words, left hemisphere dominance students are they who apply proverb "slow but sure". They think first before doing something because everything is should base on analytical procedure. In another side, those of us who are 'right-brained' prefer to see the whole picture, to have an overview; learning is a more global or holistic activity (Pritchard, 2009). The following 
points sententiously will describe the differences characteristics between left hemisphere dominance students and right one (Brown, 2007: 125).

Left hemisphere dominance students are good in some aspects like having high intellectual, good at remembering names, good at remembering to verbal instructions and explanations, experiments systematically and controls, good at making objective judgments, planned and structured, prefers established, good at processing certain information, analytic readers, reliance on language in thinking and remembering, prefers talking and writing, good at controlling feeling, not good at interpreting body language, rarely uses metaphors, and avors logical problems solving.

Right Hemisphere dominance students sometimes perform contrast behaviors like left hemisphere dominance students, they are usually intuitive, good at remembering face, responding to demonstrated or illustrated instruction well, experiments randomly and less restraint, making subjective judgments, fluid and spontaneous, prefers elusive and uncertain information, they are also synthesizing readers, reliance on images in thinking and remembering, preferring drawing and manipulating object, they are more free with feeling, good at interpreting body language, frequently uses metaphors, and favoring intuitive problems solving.

Furthermore, Prof. Dr. Conny R. Semiawan in her book mentioned left hemisphere as "disunity" and "unity" for right one (Semiawan, 2010: 59). Hannaford in Alan's book refers to a 'gestalt' hemisphere for right one and 'logic' hemisphere for other. He states:

"The name 'gestalt' comes from the group of psychologists who described the working of the human mind in a way that suggests that it is capable of working with very large 'whole' events and capable of filling in missing elements of large information sets. The gestalt hemisphere, which in most, but not all, people is the right hemisphere, deals with the whole picture; it operates intuitively and in a more random manner than the logic hemisphere. The logic hemisphere, which is usually the left hemisphere, processes information piece by piece, in sequence and in fine detail" (Pritchard, 2009: 87).

Those brief explanations indicate the diversities between left hemisphere dominance students and right one become clearer. Whatever the tendencies which make both hemispheres dominance are walking in different sides, they will go to the same purpose; learning achievement.

\section{The Definition of Multiple Choice Test}

By knowing the definition, purpose, and characteristics of test items, one will have at hand a great deal of information about a particular test item, its construction, function, and probable effectiveness (Osterlind, 1998: 18). Because of that, it is essential to open this part by explaining the definition. Further, it will point the characteristics indirectly.

Fulcher in his book explains multiple choice tests the work product is a set of responses to the items, and the observable variables are the number of correct and incorrect responses (Fulcher \& Davidson, 2007: 66). In similar corridor, Osterlind 
elaborates multiple-choice format for test items is characterized by an item with a stem sentence or phrase that presents a problem or asks a question, followed by usually two to five response alternatives (commonly it is used four, each of them are marked by a, b, c, and d) (Djiwandono, 2008: 41), one of which appropriately answers the stem. The stem should generally be in the interrogative (Osterlind, 1998: 162). In other words, multiple choices test are kind of test which the question consists of a stem and a number of options (response alternatives) from which the student has to select the correct one. The response alternatives may be complete sentences, sentence fragments, or even single words.

In multiple-choice testing the intended correct option is called the 'key' and each incorrect option is called distractors, misleads, or foils (Haladyna, 2004: 68). The key is the most appropriate answer for the question. The distracters have "job" to distract students' decision who don't understand well about the materials (Djiwandono, 2008: 41). It might say that the distractors as the traps. Only students who are mastering the lessons will save in order they can choose the right answer; the key.

\section{The Benefits of Using Multiple Choice Test}

There are some experts who have mentioned the advantages or the benefits of using multiple choice tests in their books. First view is from Osterlind. He explains that multiplechoice format for test items have a number of strengths that make it particularly wellsuited for assessing mental attributes (Osterlind, 1998: 163). It means that principal among its advantages is the fact that it offers more flexibility for assessing a diversity of content and psychological processes than can be garnered from other item formats.

Osterlind (1998) in his book remarked by quoting Nitko's statement: “Among the various types of response choice items, the multiple-choice item can be used to test a greater variety of instructional objectives" Thus, multiple choice test is commonly used for not only national examination but also in ordinary test to measure students' comprehension after passing previous materials. Even most numbers of Test of English as a Foreign Language (TOEFL test) also used it such as in one of book which guides reader to practice TOEFL in everywhere namely "EASY TOEFL; A Complete Guide to Master TOEFL" (Saifuddin, 2010).

Moreover, it is still in Osterlind's book, Haladyna and Downing (as quoted by Osterlind, 1998: 163) state that testing organizations and technical measurement experts prefer the multiple-choice format because its "sampling of content is generally superior when compared to other formats." It means that the flexibility of multiple choices for accommodating a diversity of content can be used in a variety of test instruments, whether designed for educational or psychological test. An aspect of the flexibility of the multiple choice format is that, when well-written, the format allows test of complex and sophisticated mental skills, ones that would be high up on a list of cognitive abilities (Osterlind, 1998). 
Furthermore, Osterlind (1998) states less precisely and more bluntly: good multiple choice items can assess higher order thinking skills because multiple-choice format is that it allows for a precise interpretation which can lead to important evidence for content related test validity. Considering just the positive features of the multiple-choice item format, a set of well-constructed items in this format can provide very reliable test of an examinee's true ability. The format is flexible, sophisticated, and simple to use (Osterlind, 1998). Talking about validity and reliability which are crucial as good characteristics of test, Jeremy Harmer (2001: 322)stated that a test is valid if it tests what it is supposed to test (validity) and a good test should give consistent result (reliability). Furthermore, he states:

"A test item is direct if it asks candidates to perform the communicative skill which is being tested. Indirect test items, on the other hand, try to measure a student's knowledge and ability by getting at what lies beneath their receptive and productive skills. Whereas direct test items try to be as much like real-life language use as possible, indirect items try to find out about a student's language knowledge through more controlled items, such as multiple choice questions and grammar transformation items. These are often quicker to design and, crucially, easier to mark, and produce greater scorer reliability (Harmer, 2001)."

It means that multiple choice test is an example of direct test which is easier to mark and produce reliable score. Next view comes from Prof. Dr. M. Soenardi Djiwandono. He states (Djiwandono, 2008: 42):

"The advantages of multiple-choice tests include (1) the opportunity to answer correctly by simply guessing, compared with true or false tests, (2) the range of material tests wider, (3) how to answer that simple, (4) The answer is more simple, (5) analysis which is easier to do on each test item or test overall because just based on the number or the presentation, including the calculation of the reliability of tests ".

First point means multiple choice test is better than wrong-right one whose $50 \%$ in each possibilities; right or wrong. Thus, it will decrease unwilling possibility namely guessing from students. The next three points mean multiple choice test needs short time even though there are many materials which is examined because the way to answer and to check the sheet is simply and need not long time. It needs certain mark only. The mark may a circle $(0)$, crosswise $(x)$, and checklist $(\sqrt{ })$. In addition, since the development of technology, it has been found the scanner machine to check the sheet. In seconds, every answer sheet has finished to be checked (Djiwandono, 2008). Besides that, by using multiple choice test makes the analysis of the difficulties level from test is more accurate. The analysis of the difficulties level is possible not only from each number but also from whole test whether they are easy, medium, or difficult (Djiwandono, 2008: 43).

David has also his own statements, he states that the test writer can get directly at many of the specific skills and learning he wishes to measure, multiple choices generally can be answered fairly rapidly, the test writer can include a large number of different 
tasks, scoring can be done quickly and involves no judgments as to degrees of correctness, and multiple choice tests tend to have superior reliability and validity, two important test characteristics (Harris, 1969: 7).

Validity and reliability are two important test characteristic (Harris, 1969). Validity is the central concept in testing and test (Fulcher \& Davidson, 2007: 3). Hughes in Fulcher and Davidson's book said that validity in testing and test has traditionally been understood to mean discovering whether a test 'measures accurately what it is intended to measure (Fulcher \& Davidson, 2007: 4), whereas Henning (still in same book) states that validity is process for uncovering the 'appropriateness of a given test or any of its component parts as a measure of what it is purposed to measure' (Fulcher \& Davidson, 2007). This view of validity presupposes that when the test makers write a test, they have an intention to measure something, that the 'something' is 'real', and that validity enquiry concerns counting whether a test 'actually does measure' what is intended (Fulcher \& Davidson, 2007).

Henceforth, David has his own definition of reliability. He states that reliability is meant the stability of test scores; a test cannot measure anything well unless it measures consistently (Harris, 1969: 14). Multiple choice test has its own formula in scoring and because of it, the score will always reliable. Beside reliability and validity, multiple choice item test also has the five principal purposes for educational test, they are:

The first is accountability. It means providing evidence of the performance of teachers, administrators, schools, districts, or states, relative to established standards or benchmarks, or in comparison to others, or both. Besides that in counting the score, it needs simple formula (the explanation is in next chapter). The second is decision about the students, providing data that is used in making important decisions about individual students, such as placement in academic programs, grade promotion, or graduation. The third is program evaluation, providing evidence of the outcome of a particular educational program in terms of student performance. The fourth is tracking of long-term trends. Providing evidence of changes in the performance of groups of students, such as those enrolled in a particular grade, school, or school district, or those belonging to population subgroups, etc. And the last is diagnosis. It refers providing information about students' strengths and weaknesses with regard to specific material or skills (such as proficiency in English, for example), for use in improving teaching and learning (Hakuta \& Beatty, 2000: 20).

From those views, it may be inferred that testing English as a second language by using multiple choice test is an effective way to measure students' second language acquisition. It not only because of its contain namely validity and reliability but also its number of benefit which explains above. 


\section{The Weaknesses of Using Multiple Choice Test}

It is impossible to find penny without its both flanks. This analogy also occurs in multiple choice tests. After knowing its advantages, certainly, its disadvantages will visible. Same with the previous part, this one also provides some experts.

Prof. Dr. M. Soenardi Djiwandono elaborates in detail that the weaknesses in using multiple choice test placed on its choices. It makes the test taker difficult to determine whether the students understand well about the material till they can choose best answer or just being lucky (guessing brings luck). The researcher has funny experience when she was twelve. Her friend used some lotteries to choose the answer from multiple choice tests.

Further, to minimize the guess process which might be done by students, Soenardi offers another way to apply correction for guessing (Djiwandono, 2008: 45). The students will lose some scores when they choose wrong answer with this assumption "Their score will decrease when they choose the answer based on guessing only". The following formula is used to count the score (Djiwandono, 2008: 46):

$$
\mathrm{SA}=\sum \mathrm{JB}-\left(\sum \mathrm{JS}: \mathrm{JA}\right)
$$

Note:

$\mathrm{SA} \quad=$ last score

$\sum \mathrm{JB}=$ sum of right answer

$\Sigma \mathrm{JS}=$ sum of wrong answer

JA = sum of choice answer for each items

In addition, next to the Osterlind's view, he states in his book:

"Items in the multiple-choice format also have negative aspects, some of which are the obverse of positive aspects of the format. For example, one positive feature of the format, that examinees need not produce a long, written response, can also be construed as a negative characteristic. By prescribing that examinees merely select one choice from among a very few alternatives, the multiple-choice format inhibits examinees from expressing creativity or demonstrating original and imaginative thinking. The critics charge that thorough discussion of events and their meaning is discouraged by reducing knowledge to only what can be accommodated by simple statements, since that is what fits most conveniently into the format. Some detractors of standardized testing take the criticism that multiple choice items inhibit creativity and reduce all important knowledge to superficial facts a step further by claiming that knowledge itself is "vulgarized" by the multiple-choice format. This vulgarization of knowledge is reified for these critics in the sense that multiple-choice items suggest there is one, and only one, correct answer to every problem (Osterlind, 1998: 164)."

It may be inferred that Osterlind has opinion that multiple choice test avoids students to express their answer and he judged that multiple choice is "vulgar" because it provides only one correct answer in every questions. However, Osterlind continues his statement that those denunciations of the multiple-choice item are not universally accepted. In fact, there is overwhelming proof that valid interpretations of scores from tests containing multiple-choice items can be made. 
To review this proof, one need only examine the evidence for valid score interpretations from literally hundreds of well-constructed tests. Further, the interpretations of test's scores are not limited to simple interpretations. Many times the score's interpretations are complex and sophisticated, lending further evidence that the criticism is unfounded (Osterlind, 1998). It means the weaknesses of multiple choice test is covered by both its benefit and its scores interpretations which are complex and sophisticated.

\section{METHOD}

\section{Research Design}

This research used quantitative research namely ex post facto research. It matched with the goal of this study which is comparing between right hemisphere dominance students with left hemisphere dominance students in Multiple Choice namely English one.

Donald Ary states:

"Ex post facto research is conducted after variation in the variable of interest has already been determined in the natural course of events. This method is sometimes called causal comparative because its purpose is to investigate cause-and-effect relationships between independent and dependent variables. Researchers use it in situations that do not permit the randomization and manipulation of variables characteristic" (Ary, Jacobs, Razavieh, \& Ary, 2010: 332).

\section{Population and Sample}

The population in this study is all of students at the first grade MAN 2 of Pamekasan. They consist of eight classes, namely five science classes and three social one. The sum of each class will be described in table below:

\begin{tabular}{|c|c|c|}
\hline No & Classes & Quality of Students \\
\hline 1. & Science 1 & 33 \\
\hline 2, & Science 2 & 38 \\
\hline 3, & Science 3 & 38 \\
\hline 4, & Science 4 & 38 \\
\hline 5. & Science 5 & 37 \\
\hline 6. & Social 1 & 38 \\
\hline 7. & Social 2 & 37 \\
\hline 8. & Social 3 & 35 \\
\hline \multicolumn{2}{|c|}{ Total } & 294 \\
\hline
\end{tabular}

From those numbers, the researcher took $15 \%$ of total population by using slovin formula. Then, 40 students were taken as the sample of this study so that each sample from those two groups is balance. Furthermore, simple random sampling (technique that is used to select participants for the sample so that any individual has an equal probability of being selected from the population will be used. 


\section{Research Instruments}

Two research instruments were used to collect the data. They are questionnaire and test. The closed form questionnaire were used to identify the students whether they have right dominance hemisphere or left dominance hemisphere. While test which is in this case multiple choice test of English test were used to determine the alternative hypothesis whether it is accepted or not.

\section{Data Collection Procedures}

The procedures in collecting the data are as follow; the first, Getting permission from the headmaster of MAN 2 Pamekasan to conduct this study, the researcher has spread the questionnaire sheets to entire first grade students MAN 2 of Pamekasan. Taking 40 students to represent both hemisphere dominance students; the second, after dividing the selected sample into 20 students, the researcher has grouped the samples into two categories. Then giving them multiple choice of English test which has been consulted. The third, the researcher has counted the result and comparing it by using statistics procedures.

\section{Data Analysis}

To analyze the data in this study, the researcher uses inferential analysis, namely ttest since this study will compare left hemisphere dominance students and right one that are as variable $\mathrm{X}$, and students' multiple choice score as variable $\mathrm{Y}$. The formula of $t$-test is as follow:

$$
t=\frac{M_{1}-M_{2}}{S E_{M 1-M 2}}
$$

Where:

$\mathrm{T}=\mathrm{t}$-value

$\mathrm{M}_{1} \quad$ = Mean score of first group (Left hemisphere dominance students)

$\mathrm{M}_{2} \quad$ = Mean score of second group (right hemisphere dominance students)

$\mathrm{SE}_{\mathrm{M} 1-\mathrm{M} 2}=$ Standard error difference between mean score of first group and second group.

\section{RESULTS AND DISCUSSION}

The researcher analyzed the multiple choice of English test score from both kinds of hemisphere dominance students by using t-test formula. The findings are the achievement of multiple choice of English test of left hemisphere dominance students is better than right one at the first grade MAN 2 of Pamekasan. From the surface, it can be known by checking the total score in appendix VII table 12 and 13 that left hemisphere dominance students' group gain higher score than right one. From deep side, it can be proved by the analyzing and knowing the means scores of both groups as the mean score of left hemisphere dominance students is 50.9 and the mean score of right one is 41.89 and the mean difference is 9.01 . 
The mean scores which are gotten by both hemisphere dominance students can be inferred that it is representative of multiple choice of English test achievement of the both population. In addition, it is also by knowing the $t$-value that $t$-value is higher than $t_{\text {table }}$ in significant level 5\%.

In short, based on the description of the means scores and t-value above, the researcher infers that left hemisphere dominance students achieve better in multiple choice of English test than right one at the first grade of MAN 2 Pamekasan.

That finding of this research which states left hemisphere dominance students have better and higher multiple choice of English test score performance than right one, firmly is in accordance with the explanation which is proposed by scientists and psychologists which is proved by previous research in the background that language skill is placed on the left hemisphere. That preference influences their performance in language skill, multiple choice of English test certainly. That special performance supported by left hemisphere dominance students' characteristics such as detail, scientific, rational, and everything must be based on analytical and logically thinking process. Thus, they gain higher score and better performance in multiple choice of English test which has more benefit than another technique of test.

Both kinds of the left hemisphere dominance students and right one of MAN 2 Pamekasan are statistically significant difference in multiple choice of English test. It has been seen that $t$-value is higher than $t_{\text {table }}$ in significant level $5 \%$. It is proven by the hypothesis testing of this research is accepted in significant level 5\%. In proving the hypothesis, the researcher consults $t$-value of this research to $t_{\text {table. The }} t$-value of this research is 2.16 and the $t_{\text {table }}$ is 2.03 in significant level $5 \%$ with degree of freedom 38 .

However, the researcher did not find the degree of freedom 38 in the table 17. The researcher must choose the degree of freedom which is closest to 38 , namely 35 which has value of t table 2.03 in significant level 5\% as Anas's statement that if the degree of freedom which is used in the research is not in the table, it might use the closest degree of freedom to which is applied in the research (Ary et al., 2010: 285). Further, it can be seen that $t$ value is higher than $t_{\text {table }}$ in significant level $5 \%$ ( $t$-value $>t_{\text {table }}$ or $2.16>2.03$ ). Therefore, the answer of the second research problem is there is statistically significant difference between right hemisphere dominance students and left one in multiple choice of English test in significant level 5\% only.

\section{CONCLUSION}

The research revealed that the left hemisphere dominance students at the first grade MAN 2 of Pamekasan have better English skill especially in English test by using multiple choice test technique than the right one since language skill is placed on left hemisphere which influences students' characteristics and their learning style. This preference helps the left hemisphere dominance students in gaining higher English testing score than right one. The data also shows that there is statistically significant difference 
between both hemisphere dominance students at the first grade MAN 2 of Pamekasan in English testing skill comparison in significant level 5\%. It is proven by the result of data analysis and by comparing $t$-value with $t_{\text {table }}$ in significant level $5 \%$. The result denotes that $t$-value is 2.16 whereas $t_{\text {table }}$ is 2.03 in significant level $5 \%$. Therefore, all figures should consider this result of study as an input in order that they can create some new program in supporting English language testing based on students' dominance of hemisphere.

\section{REFERENCES}

Ary, D., Jacobs, L. C., Razavieh, A., \& Ary, D. (2010). Introduction to research in education (8th ed). Belmont, CA: Wadsworth.

Brown, H. D. (2000). Principles of Language Learning and Teaching (4th ed.). San Fransisco: Longman.

Brown, H. D. (2007). Principles of Language Learning and Teaching (5th ed.). San Fransisco: Longman.

Busan, T. (2005). Brain Child (Translated by Marselita Harapan). Jakarta: Gramedia.

Capacchione, L. (2001). The Power of Your Other Hand. USA: New Page Books.

Chaer, A. (2009). Psikolinguistik: Kajian Teoretik. Jakarta: Rineka Cipta.

Chomsky, N. (1994). Language File. Ohio: Ohio University State.

Décosterd, M. L. (2010). Right Brain/Left Brain President. Colorado: Praeger.

Djiwandono, S. (2008). Tes Bahasa. Jakarta: PT. Indeks.

Ellis, R. (1994). The Study of Second Language Acquisition. New York: Oxford University Press.

Emmorey, K. (2002). Language, Cognition, and the Brain. London: Lawrence Erlbaum Associates Publisher.

Fulcher, G. (2010). Practical Language Testing. London: Hodder Education.

Fulcher, G., \& Davidson, F. (2007). Language Testing and Test. London: Routledge.

Hakuta, K., \& Beatty, A. (2000). Testing English Language Learners in U.S. Schools. Washington, D.C.: National Academy Press.

Haladyna, T. M. (2004). Developing and Validating Multiple Choice Test Items (3rd ed.). London: Lawrence Erlbaum Associates Publishers.

Harmer, J. (2001). The Practice of English Language Teaching. London: Cambridge University Press.

Harris, D. P. (1969). Testing English as a Second Language. Bombay: Tata McGraww-Hill Publishing Company Ltd.

Harrish, J. (2002). What Every Parent Needs to Know About Standardized Test; How to Understand the Test and Help Your Kids Score High. New York: McGraw-Hill.

Kalat, J. W. (2011). Biopsikologi (Translated by Dhamar Pramudito). Jakarta: Salemba Humanika.

Muhammad, A. bin. (2008). Ibnu Katsir (Translated by Abu Ihsan). Jakarta: Pustaka Imam Syafi'i. 
Osterlind, S. J. (1998). Constructing Test Items. New York: Kluwer Academic Publishers.

Pritchard, A. (2009). Ways of Learning. London: Routledge.

Saifuddin, I. A. (2010). Easy TOEFL. Yogyakarta: Buku Biru.

Semiawan, C. R. (2010). Kreativitas Keberbakatan. Jakarta: Indeks.

Siahaan, S. (2008). Issues in Linguistics. Yogyakarta: Graha Ilmu.

Solso, R. L. (2007). Psikologi Kognitif (Translated by Mikael Rahardanto). Jakarta: Erlangga.

Tea, T. (2009). Inpiring Teaching. Jakarta: Gema Insani Press.

The Qur'an Arabic Text with Corresponding Meanings. (1997). Riyadh: Abul Qosim Publishing House. 
Laily Komaril Syafrilia, and Mosleh Habibullah, The Comparison Between Right Hemisphere... 